\title{
Vitamin A and the eye: an old tale for modern times
}

\section{A vitamina A e o olho: uma velha história em tempos modernos}

Jacqueline Ferreira Faustino ${ }^{1}$, Alfredo Ribeiro-Silva ${ }^{2}$, Rodrigo Faeda Dalto ${ }^{1}$, Marcelo Martins de Souza ${ }^{1}$, João Marcello Fortes Furtado ${ }^{1}$, Gutemberg de Melo Rocha ${ }^{3}$, Monica Alves ${ }^{4}$, Eduardo Melani Rocha ${ }^{1}$

\begin{abstract}
Clinical presentations associated with vitamin A deficiency persist in poor regions globally with the same clinical features as those described centuries ago. However, new forms of vitamin A deficiency affecting the eyes, which have become widespread, as a result of modern societal habits are of increasing concern. Ophthalmic conditions related to vitamin A deficiency require the combined attention of ophthalmologists, pediatricians, internists, dermatologists, and nutritionists due to their potential severity and the diversity of causes. As the eyes and their adnexa are particularly sensitive to vitamin A deficiency and excess, ocular disturbances are often early indicators of vitamin A imbalance. The present review describes the clinical manifestations of hypovitaminosis A with an emphasis on so-called modern dietary disorders and multidisciplinary treatment approaches. The present review also discusses the relationship between retinoic acid therapy and dry eye disease.
\end{abstract}

Keywords: Vitamin A deficiency/complications; Eye manifestations; Bariatric surgery; Blepharoplasty; Refractive surgical procedures; Xerophthalmia

\section{RESUMO}

As apresentações clínicas associadas à deficiência de vitamina A persistem em regiões pobres ao redor do mundo com os mesmos achados clínicos descritos há séculos. No entanto, novas formas de problemas causados pela vitamina A afetam os olhos, estão associados com os hábitos da sociedade moderna e tem causado preocupação. Eles exigem a atenção dos oftalmologistas, pediatras, internistas, dermatologistas e nutricionistas, devido à sua gravidade e diversidade de causas. Uma vez que os olhos e seus anexos são órgãos muito sensíveis à deficiência e excesso de vitamina A, manifestações oculares podem ser indicadores precoces do desequilíbrio de vitamina A. Essa revisão traz as manifestações clínicas de hipovitaminose A enfatizando os chamados distúrbios dietéticos modernos eformas de abordagem multidisciplinar. Etambém traz evidências sobre a relação entre a terapia com ácido retinóico e doença do olho seco.

Descritores: Deficiência de vitaminaA/complicações; Manifestaçõesoculares; Cirurgia bariátrica; Blefaroplastia; Procedimentos cirúrgicos refrativos; Xeroftalmia

\section{INTRODUCTION}

Night blindness, xerophthalmia, Bitot's spot, keratitis, and keratomalacia are well-known clinical manifestations of hypovitaminosis $A^{(1)}$. However, this condition is classically related to food deprivation associated with malabsorption syndrome resulting from poverty and/or chronic disease ${ }^{(1-3)}$.

The present review aims to inform health professionals of the modern presentations, causes, associated systemic diseases, and risk factors of hypovitaminosis $\mathrm{A}$. The utility of retinoic acid application for the treatment of skin diseases and dry eye is also discussed(4). Herein, we present the clinical presentation of hypovitaminosis $A$ and discuss strategies for the investigation and treatment of the causes and consequences of hypovitaminosis $A$ and side effects of the use of retinoic acid ( $a$ form of vitamin $A$ ) in dermatological and oncological therapies.

\section{HISTORY}

The classical clinical presentation of the disease currently known as vitamin A deficiency was first described in antique medical documents of the ancient Egyptian civilization, although underlying me- chanisms were elucidated more recently. The causes of deficiencies in the micronutrient vitamin A, the biochemical vitamin A pathway, food sources of retinol (vitamin A) and its metabolites, and the physiological roles of vitamin A have only begun to be understood since the $20^{\text {th }}$ century ${ }^{(5-9)}$ (Figure 1; Table 1).

Interestingly, one of the most complete and objective descriptions of the clinical manifestations of hypovitaminosis A was published decades before the specific underlying cause was known by the Brazilian ophthalmologist, Manoel da Gama Lobo, in $1865^{(10)}$. Dr. Gama Lobo reported four cases of children, all descendants of slaves, with ocular disease who subsequently developed lung and digestive disorders before ultimately dying. In this report, the disease was termed Ophthalmia Braziliana, and the clinical progression was comprehensively detailed. Food deprivation was identified and credited to the practice of extensive monoculture in the farms of Southeast Brazil, in that century dedicated to the production of coffee and sugar.

Dr. Gama Lobo attributed the signs and symptoms observed in his patients to the poor diet of slaves and their descendants, a problem that he never saw in his homeland to north of the country

\footnotetext{
Submitted for publication: September 8, 2015

Accepted for publication: October 20, 2015

Departamento de Oftalmologia, Otorrinolaringologia e Cirurgia de Cabeça e Pescoço, Faculdade de Medicina de Ribeirão Preto, Universidade de São Paulo, Ribeirão Preto, SP, Brazil.

Medicina de Ribeirāo Preto, Universidade de São Paulo, Ribeirão Preto, SP, Brazill. de São Paulo, Ribeirão Preto, SP, Brazil.

Departamento de Medicina Social, Faculdade de Medicina de Ribeirão Preto, Universidade de São Paulo, Ribeirão Preto, SP, Brazil.

4 Departamento de Oftalmologia e Otorrinolaringologia da Faculdade de Ciências Médicas, Universidade Estadual de Campinas, Campinas, SP, Brazil.
}

Funding: This study was supported by CAPES, CNPq, FAPESP, FAEPA, and NAP-FTO-USP. Disclosure of potential conflicts of interest: None of the authors have any potential conflicts of interest to disclose.

Corresponding author: Eduardo Melani Rocha. Department of Ophthalmology, Otorhinolaryngology and Head \& Neck Surgery, School of Medicine at Ribeirao Preto, University of Sao Paulo. Av. Bandeirantes, 3.900 - Ribeirão Preto, SP - 14049-900 - Brazil - E-mail: emrocha@fmrp.usp.br 
where agriculture production was dedicated to local consumption and therefore more variable and abundant. At the end of his report, Dr. Gama Lobo called the attention of legislators to the need for laws aimed at preventing the sequence of problems he outlined. His paper was published in Portuguese and in German but is relatively unknown to the majority of the medical community, although it is now freely available online $\mathrm{e}^{(11,12)}$.

Recent epidemiologic data from Brazil in a study population of 3,499 children aged between 6 and 59 months and 5,698 women aged between 15 and 49 years revealed that hypovitaminosis $A$ is present in all five regions of Brazil with a prevalence of $17.4 \%$ and $12.3 \%$ among children and women, respectively ${ }^{(13)}$. The highest prevalence was found to be in urban areas and the northeastern and southeastern regions of the country.

\section{CLASSIC DISEASE}

The typical medical scenarios leading to hypovitaminosis A are low food intake, intestinal parasitosis, malabsorption syndromes, and diets containing low amounts of vitamin A (Figure 2).

Hypovitaminosis A is classically caused by food deprivation. It is present in rural areas and the peripheries of large cities in South Asia, Africa, and Latin America, and the poor communities of large cities of developed countries ${ }^{(14-17)}$. The most vulnerable individuals are children and pregnant women. The prevalence of hypovitaminosis A can reach $50 \%$ in children under 6 years of age in certain areas ${ }^{(18)}$. Laboratory confirmation of the diagnosis of hypovitaminosis $A$ is defined as a serum retinol level $<0.3 \mathrm{mg} / \mathrm{l}$ or $0.7 \mu \mathrm{M}^{(19)}$.
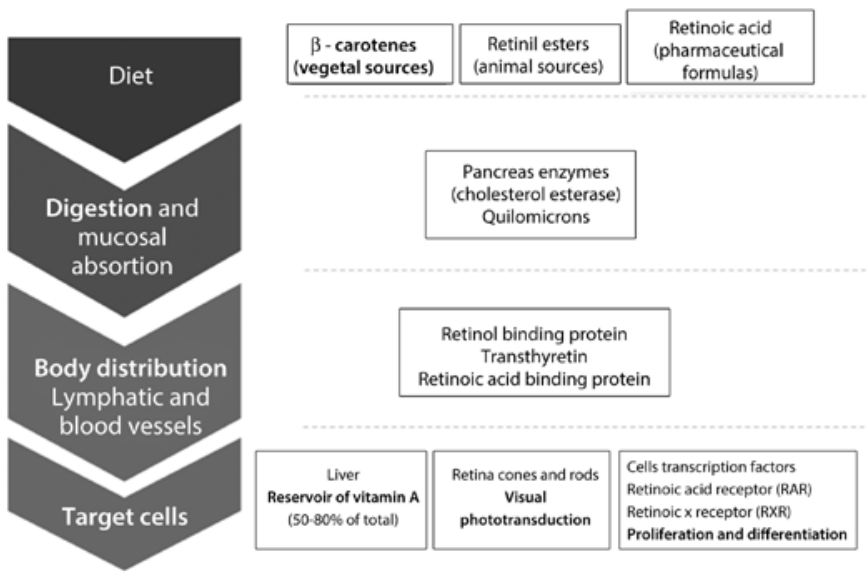

Figure 1. Metabolic steps underlying vitamin A deficiency from the dietary level to tar get cells.
In addition to ocular problems, hypovitaminosis $\mathrm{A}$ also predisposes individuals to retarded growth, infertility, congenital malformations, infections, and early mortality ${ }^{(18,20)}$. The issue of vitamin A deficiency in these populations, distributed in more than 45 countries, has been the target of international preventive programs of vitamin A supplementation and periodic evaluation ${ }^{(16,18,19)}$.

Individuals suffering from food deprivation and malabsorption are often infected with intestinal parasite diseases, such as Ascaris lumbricoides and Ancilostomides, Giardia lamblia, which may aggravate the inflammatory background and the signs and symptoms of hypovitaminosis $\mathrm{A}^{(21-24)}$.

Other well-known causes of vitamin A deficiency can be grouped into conditions associated with malabsorption syndrome. The treatments of several diseases that cause digestive disturbances and/or absorption of lipids and vitamin A have improved in recent decades leading to increased life expectancy and improved the clinical control of hypovitaminosis A allowing the majority of patients to lead a normal life. However, the majority of these patients will develop xerophthalmia (the specific term for hypovitaminosis A-related dry eye), which may progress to more severe ocular damage and other clinical manifestations of vitamin A depletion ${ }^{(25-27)}$.

Acquired diseases associated with malabsorption syndrome known to cause hypovitaminosis A include chronic pancreatitis caused by chronic alcoholism, liver and pancreas autoimmunity, Crohn's disease, and ulcerative colitis, among other diseases affecting the digestive system ${ }^{(28)}$.

Congenital diseases associated with malabsorption syndrome and hypovitaminosis A include cystic fibrosis and short bowel syndrome, among other genetic diseases that may impair intestinal vitamin A absorption in individuals with normal or high oral intake of retinoid and carotenoids $(2,29,30)$

The fourth group of conditions that classically cause hypovitaminosis $A$ is those that may initially lead to malabsorption syndrome but later progresses to impaired hepatic storage of vitamin A. Biliary cirrhosis, chronic hepatitis, and chronic cirrhosis caused by toxic agents, viruses, and other causes may lead to hypovitaminosis A and should be screened for and treated by parenteral vitamin A supplementation according to body mass index and level of vitamin A deficiency ${ }^{(31)}$.

\section{MODERN DISEASES ASSOCIATED WITH HYPOVITAMINOSIS A}

In recent decades, the conditions known to induce hypovitaminosis A have been classified into four groups. Despite their varying prevalence, such conditions should be carefully considered by ophthalmologists during routine clinical practice.

Modern causes of hypovitaminosis A that may also lead to xerophthalmia and other eye diseases and cause blindness are shown in (Figure 2 and Table 2) and comprising voluntary ingestion of low vitamin A diets or restrictive diets (e.g., vegetarian or cafeteria diets), psychiatric eating disorders (e.g., anorexia and bulimia), bariatric

Table 1. Vitamin A nomenclature

\begin{tabular}{|c|c|c|}
\hline Name & Group & Characteristics \\
\hline Retinoids & Vitamin A and natural or synthetic derivate & Similar chemical polyenes and polar end groups \\
\hline Carotenes & a-Carotene, $\beta$-carotene, $\gamma$-carotene, and the xanthophyll $\beta$-cryptoxanthin & B-ionine rings \\
\hline Vitamin A & Group of lipophilic nutritional compounds & Essential and broad effects on chordate animal bodies \\
\hline Provitamin A & Carotenes and retinyl esters & Dietary and pharmaceutical sources of vitamin A \\
\hline Retinoic acid & Metabolite of vitamin A & Transcription factor binding to cell nuclear receptors \\
\hline Retinal & Form of vitamin A & Essential for vision function \\
\hline Retinol & Form of vitamin A & Growth and development functions \\
\hline Tretinoin & All trans retinoic acid & Pharmaceutical formulas \\
\hline
\end{tabular}

$1 \mathrm{IU}$ of vitamin $\mathrm{A}=0.3 \mu \mathrm{g}$ retinol $=0.34 \mu \mathrm{g}$ retinil acetate $=0.6 \mu \mathrm{g} \beta$-carotene. 
surgeries mimicking malabsorption syndrome, and chronic diseases that affect organs involved in vitamin A digestion or clearance (e.g., Sjögren's syndrome and kidney failure).

Restrictive diets resulting from dietary behaviors may lead to a status of hypovitaminosis $\mathrm{A}$ and the consequences mentioned above. Diets adopted in conjunction with drugs to reduce appetite, diets with monotonous ingredients, and diets with limited sources of animal ingredients containing retinol and beta carotene (meat and

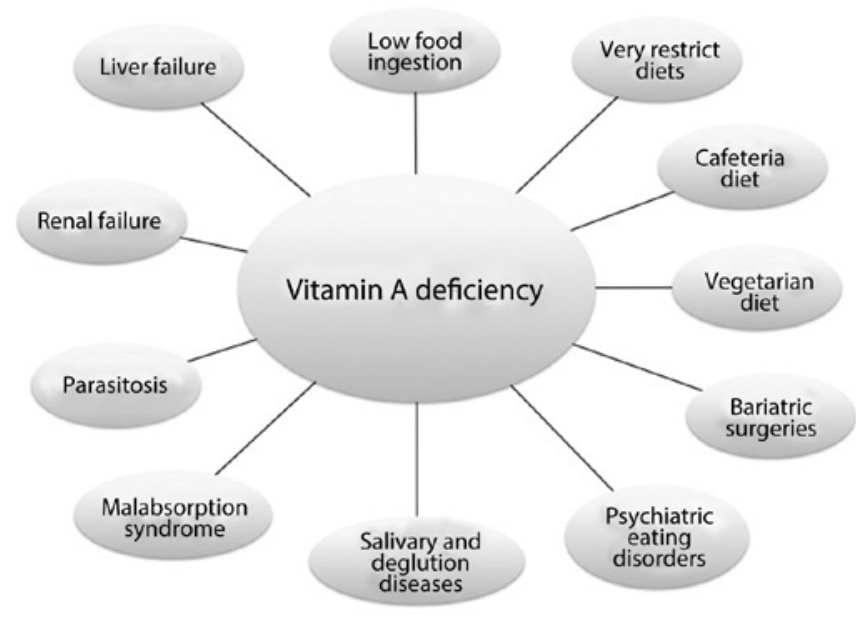

Figure 2. Classic and modern causes of hypovitaminosis A. dairy products such as milk, eggs, and their derivatives) are typically followed in the belief they will offer better control or prevention of certain diseases or improve general health ${ }^{(32-35)}$.

Exclusively vegetarian diets particularly put children and pregnant woman at increased risk of hypovitaminosis $A$ as the conversion of beta carotenes present in vegetables to retinol is limited during digestion and the availability of vitamin A for absorption and hepatic storage is $<20 \%$ of dietary vitamin $A$ content ${ }^{(1)}$.

The so-called cafeteria diet or competitive food, based on refreshing sodas and industrialized food, is predominantly composed of carbohydrates and lipids of vegetal source and provides insufficient amounts of dietary vitamin A. Accordingly, such diets could be considered causes of hypovitaminosis A and associated ocular problems in patients with excessive habits related to these diets ${ }^{(36)}$.

The second group of causes of hypovitaminosis A includes the psychiatric eating disorders, anorexia, and bulimia nervosa, recognized as major, growing health problems with severe clinical complications, and high mortality. Both can cause hypovitaminosis A due to chronic dietary disturbances. The complexity of such conditions must be recognized in the context of early signs of xerophthalmia and should be managed in parallel with psychiatric specialists ${ }^{(37,38)}$.

Bariatric techniques for the treatment of obesity include jejunoileal bypass and stomach reduction to induce weight loss by malabsorbtive and restrictive mechanisms ${ }^{(39-41)}$. Patients require vitamin supplementation following these procedures; however, a recent study in Brazil demonstrated that even before bariatric surgery a relative amount of patients already have hypovitaminosis $A$, and that this prevalence increases 30 and 180 days after the procedure ${ }^{(42)}$. In patients with no compliance for a period of weeks or months, ophthalmologists may evaluate the initial manifestations of hypovitaminosis A. Special attention should be paid to patients undergoing oculoplastic or refractive surgeries as their nutritional status may be subclinical

Table 2. Major causes of hypovitaminosis A and diagnosis guidelines

\begin{tabular}{|c|c|}
\hline Major causes of deficiency of vitamin A & Description \\
\hline Primary deficiency & $\begin{array}{l}\text { Low dietary intake of vitamin A } \\
\text { Food source: liver beef, damascus, spinach, cabbage, milk, carrot, and butter } \\
\text { Diagnosis: food intake history, liver function, and vitamin A serum levels }\end{array}$ \\
\hline Restrictive and monotonous diets & $\begin{array}{l}\text { Restricted intake of sources of vitamin A and consumption of the same group of food for many months } \\
\text { Eating disorders: psychiatric, cafeteria diet, and vegetarian } \\
\text { Diagnosis: food intake history. Physical signs. Blood vitamin A levels }\end{array}$ \\
\hline Malabsorption syndrome & $\begin{array}{l}\text { Reduction in uptake and mucosa transport of digested nutrients to the blood stream } \\
\text { Diagnosis: diarrhea, steatorrhea, weight loss, anemia, hyperkeratosis, and acrodermatitis. Blood examination to check } \\
\text { pancreas and liver function. Stool analysis (fat, parasites) }\end{array}$ \\
\hline Bariatric surgery & $\begin{array}{l}\text { Surgery to treat obesity and associated diseases is divided into restrictive, disabsorptive, and mixed techniques and } \\
\text { often mimics malabsorption syndrome } \\
\text { Diagnosis: surgical history, use of vitamin supplements, bowel habits. Food intake history. Physical signs. Blood levels } \\
\text { of vitamin A. Stool analysis (fat) }\end{array}$ \\
\hline Short bowel syndrome & $\begin{array}{l}\text { Mesenteric vascular disease typically caused by congenital obstruction, thrombosis, and other diseases requiring } \\
\text { bowel resection } \\
\text { Diagnosis: diarrhea, fatigue. Blood levels of vitamin A. Stool analysis (fat) }\end{array}$ \\
\hline Liver failure & $\begin{array}{l}\text { Loss of liver digestive and storage functions due to alcohol toxicity, virus infection, or other causes. Malabsorption } \\
\text { mechanisms and signs may be present. } \\
\text { Diagnosis: blood levels of liver enzymes and vitamin A, virus serology. Stool analysis (fat) }\end{array}$ \\
\hline Chronic pancreatitis & $\begin{array}{l}\text { Loss of pancreas exocrine function affecting digestion. Malabsorption mechanisms and signs may be present } \\
\text { Diagnosis: blood levels of pancreas enzymes and vitamin A. Stool analysis (fat) }\end{array}$ \\
\hline Cystic fibrosis & $\begin{array}{l}\text { Inherited disease affecting chloride channels leading to exocrine gland dysfunction. Malabsorption mechanisms and } \\
\text { signs may be present } \\
\text { Diagnosis: low weight gain in infancy, progressive malnutrition, chronic cough with hypersecretion, chronic sinusitis, } \\
\text { biliary cirrhosis, diabetes, respiratory infections and infertility. Sodium and chloride levels in sweat }\end{array}$ \\
\hline Salivary and deglutition diseases & $\begin{array}{l}\text { Swallowing problems due to xerostomia, tooth problems, and/or muscular deglutition dysfunction. Example: Sjögren's } \\
\text { syndrome } \\
\text { Diagnosis: oral and dental examination and salivary flow rate }\end{array}$ \\
\hline
\end{tabular}


and cause disturbances in ocular surface homeostasis and wound healing leading to poor outcomes and serious ocular complications ${ }^{(40)}$.

Patients with the above-mentioned conditions may share a number of characteristics including individual concern and anxiety regarding body image, health, and satisfaction with food consumption.

The fourth class of modern causes of hypovitaminosis A that may contribute to or worsen ocular surface diseases is the chronic disease leading to chronic impairment of the organs involved in digestion and clearance of vitamin A metabolites (Figure 1). Although the majority of these diseases are not new, improvements in therapeutic approach have allowed affected patients to lead longer and more active lives. Similarly, vitamin A deficiency may be neglected in patients receiving frequent healthcare.

Within this group, the diseases causing severe dry mouth, such as head and neck radiotherapy and Sjögren's syndrome, may limit deglutition and digestion and impose dietary restrictions that may lead to hypovitaminosis $A^{(43,44)}$. Therefore, dietary habits and vitamin A levels should be evaluated in patients presenting the diseases described above and ocular surface complications. Although patients commonly present with dry eye disease associated with these conditions, the clinical picture may be aggravated by hypovitaminosis $\mathrm{A}$.

Renal failure and hemodialysis are associated with dry eye disease and ocular surface changes in diabetic and nondiabetic patients ${ }^{(45,46)}$. There is currently controversy regarding lower vitamin A levels in such patients as renal failure reduced the reliability of traditional methods of measuring vitamin A levels. However, lower blood vitamin A levels have been shown to be associated with higher morbidity and mortality in these patient populations ${ }^{(47,48)}$. Recently, a case of night blindness and compatible retinal changes was described in a hemodialysis patient with apparent normal levels of serum retinol that were corrected with retinol palmitate treatment ${ }^{(49)}$.

\section{SIDE EFFECTS OF VITAMIN A MEDICAL USE}

The utility of vitamin A topical eye drop administration in treating dry eye has been comprehensively investigated ${ }^{(50,51)}$. Vitamin A topical eye drops may also have utility in the treatment of skin diseases and specific types of cancer including ocular surface neoplasia ${ }^{(52,53)}$. However, excessive vitamin A intake is known to induce gastric and neural side effects such as abdominal and head pain, nausea, and irritability ${ }^{(54,55)}$. These symptoms may be aggravated by chronic use of vitamin A eye drops and lead to the development of blurred vision and pseudotumor cerebri(56-58). A clinical history of dry skin and mucosa, nausea, and retinoic acid intake in meals or pharmaceutical formulations should inform suspicion of acute and chronic side effects or consequences of excessive vitamin A dosing.

Recently, two publications reviewed the mechanisms underlying the induction of meibomian gland dysfunction and dry eye symptoms by systemic retinoic acid therapy for acne. The authors discussed the effects of systemic and topical skin or ocular application of different forms and doses of vitamin A formulations. Moreover, it was persistent meibomian gland dysfunction after systemic retinoic acid discontinuation was reported ${ }^{(4,52)}$.

\section{CASE REPORTS}

Case report 1: A 2-year-old boy presented with a history of consecutive episodes of hordeola affecting the upper and lower lids of both eyes over the preceding 12 months. The patient had a history of photophobia and crying without tears. Previous ocular treatment included lubricants and antiallergic eye drops. The patient was an only child with no other personal or family antecedents. His dietary habits were based on soft drinks and junk food between meals with deficient intake of meat, milk derivatives, vegetables, and fruits. Swollen lids and hordeola affecting both eyes were observed on examination. He was able to fix and follow light projection with both eyes but was unable to perform visual acuity testing. Slit lamp examination demonstrated mild punctate keratitis and an epithelial defect in the right cornea. The rest of the ocular examination was normal. His body weight matched the 50th percentile for age and sex $(12.7 \mathrm{~kg})$; however, his height was in the tenth percentile $(84 \mathrm{~cm})$. Laboratory testing was requested and identified hypochromic and microcytic anemia with low blood levels of iron and retinol $(32.7 \mu \mathrm{g} / \mathrm{dl}$ and $0.20 \mathrm{mg} / \mathrm{l}$, where the normal levels for children are $50-150 \mu \mathrm{g} / \mathrm{dl}$ and 0.30-0.80 mg/l, respectively).

Clinical findings and laboratory testing indicated the chronic presence of hordeola, syndrome sicca, growth retardation, and anemia were all consequences of a diet deficient in essential elements such as vitamin $\mathrm{A}$ and iron (Fe). The diet was reoriented, and the child was maintained under close observation by his pediatrician until clinical signs improved fully.

Case report 2: A 71-year-old woman presented with decreased vision and pain in the left eye (OS) for 20 days and a diagnosis of corneal ulcer. She was receiving antibiotic and corticosteroids eye drops at the time of presentation. She had previously undergone cataract surgery in both eyes 2 months prior to this presentation. Her medical history was noncontributive except for inappetence and weight loss of approximately $10 \mathrm{~kg}$ over the preceding year. Her visual acuity was 0.5 in her right eye (OD) and counting fingers at $1 \mathrm{~m}$ OS. Biomicroscopic examination revealed conjunctiva hyperemia and a $1.5 \mathrm{~mm}$ by $2.5 \mathrm{~mm}$ corneal ulcer without secretion or infiltration. A diagnosis of microbial keratitis was made, and eye drops were changed accordingly. During follow-up, she developed a corneal ulcer OD and the ulcer in the OS worsened. Severe corneal punctate fluorescein staining and conjunctival Rose Bengal staining were observed in both eyes. The Schirmer test without anesthesia was zero in both eyes. Her salivary flow was $0.06 \mathrm{ml} / \mathrm{min}$ (normal values $>0.1 \mathrm{ml} / \mathrm{min}$; Figure 3). Laboratory tests were positive for SSa and SSb (anti-Ro and anti-La antibodies, respectively), and blood levels of vitamin A were $0.2 \mathrm{mg} / \mathrm{l}$. A minor salivary gland biopsy demonstrated leukocyte infiltration with focal organization, ductal dilation, and extensive fibrosis replacing acinar structures. The focus score was graded 4. During evaluations, the patient developed corneal melting OD and underwent penetrant keratoplasty. The present findings indicated a diagnosis of Sjögren's syndrome aggravated by hypovitaminosis A. After a period of corticosteroids and vitamin A therapy, her general and ocular symptoms improved. Her case illustrates a delicate combination of causes of sicca syndrome (Sjögren's syndrome and hypovitaminosis A) leading to a severe presentation. The extensive fibrosis of salivary gland structures, almost completely replaced by fibrosis, may be a consequence of concurrent disease and ageing (Figure 3 D).

Case report 3: A 22-year-old woman presented with ocular pain, lid edema, and thick tearing for 5 months not improved by lubricants, cyclosporine eye drops, or bandage contact lenses. She reported a habit of mucous fishing. Her previous medical history included myopia, allergy, and acne vulgaris. She had been prescribed a 6-month course of oral isotretinoin 6 years previously without side effects and again 6 months prior to the current complaint. Examination revealed skin scarring, meibomian gland dysfunction, and punctate and filamentary keratitis that was worse OD (Figure 4). The tear film breakup time was $3 \mathrm{~s}$ in both eyes and the tarsal conjunctiva presented papillary reaction. The Schirmer test without anesthesia was zero in OD and $2 \mathrm{~mm}$ in OS, and her salivary flow rate was $0.033 \mathrm{ml} / \mathrm{min}$. Laboratory testing was negative for hormonal abnormalities, and cystic fibrosis and her vitamin A blood levels were $0.4 \mathrm{mg} / \mathrm{l}$. Tests for autoimmune diseases were negative for SSa and SSb, rheumatoid factor, and antinuclear antibody. Her condition was attributed to a side effect of isotretinoin treatment that had persisted after an 18-month interruption of oral isotretinoin intake. Her case corroborates previous reports of vitamin A-induced dry eye and represents a severe form of this condition that persisted after discontinuation of the causative medication. 


\section{INVESTIGATION}

Hypovitaminosis A should be suspected in all cases of night blindness, ocular surface foreign body sensation, and photophobia without other evident causes. Crying without tearing is another relevant symptom of hypovitaminosis A. Recurrent hordeolum, meibomian gland dysfunction identified by gland dropout or inflammation with thickened lipid secretion, corneal epithelial defect, conjunctiva metaplasia (where Bitot's spot is an advanced form and a hallmark), and diffuse punctate keratitis also represent signs suspicious for hypovitaminosis A.

In all patients suspected to have hypovitaminosis A, a dietary intake and nutritional habits enquiry must be conducted, with previously validated evaluation models available. In children, investigations of height and weight gain during the management period may also have utility.

The utility of blood vitamin A levels measurements is broadly accepted, and a classification system established by the World Health Organization has defined low vitamin A levels as serum retinol concentrations $<0.3 \mathrm{mg} / \mathrm{l}$ or $0.7 \mu \mathrm{M}$. There have been concerns regarding
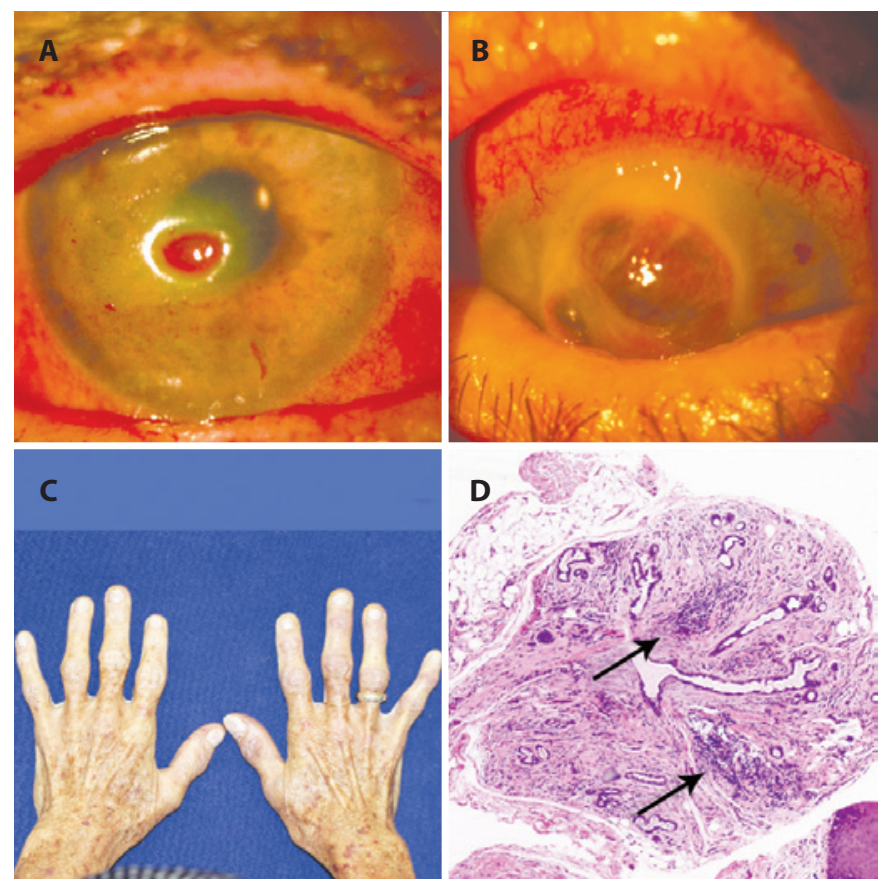

Figure 3. A 71-year-old woman with bilateral corneal ulcers, weight loss, and features of autoimmune disease affecting her hands. (A) Slit lamp examination demonstrating a corneal ulcer OD. (B) OD corneal melting. (C) Body aspect of weight loss. (D) Histology of a minor salivary gland with leukocyte focal infiltration, ductal dilation, and extensive fibrosis replacing acinar structures (200x). Her condition was attributed to a combination of dryness caused by Sjögren's syndrome and hypovitaminosis A.
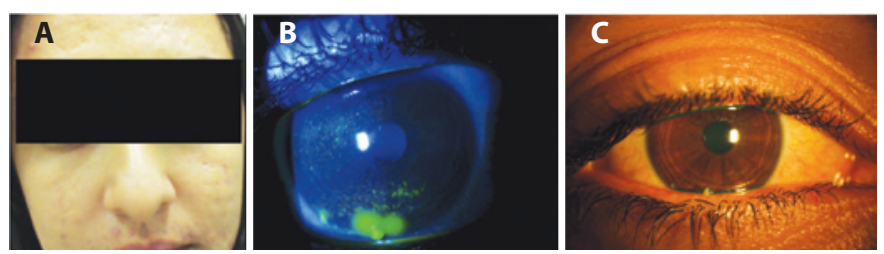

Figure 4. A 22-year-old woman with skin scarring secondary to acne vulgaris (A). Her meibomian glands were found to be dysfunctional (B), and her cornea has punctate with evidence of filamentary keratitis (C). Her condition was attributed to systemic and topical retinoic acid skin treatment. the reliability of blood concentration measurements as the liver is able to sustain normal levels even in extremely vitamin A-deficient states $^{(19,59,60)}$

Other blood tests including complete blood count, protein, albumin, micronutrients, electrolyte concentrations, and stool fat microscopy have all demonstrated utility in assessing vitamin A deficiency severity. In addition, liver function tests, serology for hepatitis, and sweat sodium chloride test values $>60 \mathrm{mM}$ may aid in distinguishing between liver diseases and cystic fibrosis, respectively.

Ocular surface assessments may be performed with vital staining and tear secretion measurements (fluorescein dye and Schirmer's test). Corneal and conjunctival impression cytology allows documentation of ocular surface epithelial metaplasia, square and speculate cells morphology, reduced nuclear size, and the absence or paucity of goblet cells on microscopy. Ocular surface assessments have demonstrated utility as simple and mildly invasive methods of recording and monitoring hypovitaminosis $\mathrm{A}$ in early xerophthalmia ${ }^{(61)}$.

\section{CONCLUSION}

The major aim of treatment is to restore vitamin A levels in cases of hypovitaminosis and reduce exposure in conditions associated with side effects of oral or skin topical vitamin A use. Details regarding dosage and administration routes are outside the scope of the present review, as they are dependent on the underlying cause, patient characteristics, and severity of individual cases.

Healthcare professionals attending poor populations and patients with chronic malabsorption syndrome, hepatic, and other related diseases should be familiar with the classic causes of hypovitaminosis A. The modern causes of hypovitaminosis A do not have the same magnitude in terms of prevalence but should be considered by ophthalmologists in daily clinical practice. Hypovitaminosis A can cause blindness and corneal opacity, but it is also an important cause of morbidity and mortality.

Increased suspicion of hypovitaminosis A due to ocular surface symptoms and signals should direct prompt investigation of nutritional and digestive problems followed by interdisciplinary management allowing early diagnosis and treatment of the causes and effects of the majority of diseases related to hypovitaminosis $\mathrm{A}$.

\section{REFERENCES}

1. Sommer A. Xerophthalmia and vitamin A status. Prog Retin Eye Res. 1998;17(1):9-31.

2. Cella W, Urbano AP, Vinhadelli WS, Donatti M, Rocha EM. Xerophthalmia secondary to short bowel syndrome. J Pediatr Ophthalmol Strabismus. 2002;39(2):125-7.

3. Whitcher JP, Srinivasan M, Upadhyay MP. Corneal blindness: a global perspective. Bull World Health Organ. 2001:79(3):214-21.

4. Moy A, McNamara NA, Lin MC. Effects of isotretinoin on meibomian glands. Optom Vis Sci. 2015;92(9):925-30.

5. McCollum EV, Davis M. The necessity of certain lipins in the diet during growth. J Bio Chemistry. 1913;15(1):167-75.

6. Wolbach SB, Howe PR. Tissue changes following deprivation of fat-soluble a vitamin J Exp Med. 1925;42(6):753-77

7. Vandorp DA, Arens JF. Biological activity of vitamin-a acid. Nature. 1946;158:158-60.

8. Dowling JE, Wald G. The biological function of vitamin-a acid. Proc Natl Acad Sci USA 1960;46(5):587-608.

9. Biesalski HK, Grimm P. Pocket Atlas of Nutrition. Stuttgart, Germany: George Thieme Verlag KG; 2005. 400 p.

10. Gama Lobo M. Da ophthalmia braziliana (About the Brasilian ophthalmia). Gaz Méd Lisboa. 1865;28(16):430-4.

11. de Vasconcelos Fde A, Santos LM. [A tribute to Manoel da Gama Lobo (1835-1883), pioneer in the epidemiology of vitamin A deficiency in Brazil]. Hist Cienc Saude Manguinhos. 2007;14(4):1341-56. Portuguese.

12. Gama Lobo M. Da ophthalmia braziliana (About the Brasilian ophthalmia). Gaz Méd Lisboa. 1865:28(17):466-9.

13. Vannucchi H, Vítolo MR, Jordão Junior AA. Micronutrientes. Brasilia-DF: Ministério da Saúde, Centro Brasileiro de Análise e Planejamento; 2009.

14. Spannaus-Martin DJ, Cook LR, Tanumihardjo SA, Duitsman PK, Olson JA. Vitamin A and vitamin $E$ statuses of preschool children of socioeconomically disadvantaged families living in the midwestern United States. Eur J Clin Nutr. 1997;51(12):864-9. 
15. Melo AM, de Carvalho RA, Figueiredo JF, Vannucchi H, Jordao Junior A, Rodrigues ML. Serum vitamin A levels in patients with ocular lesions attributable to noncomplicated malaria in the Brazilian Amazon region. Trans $\mathrm{R}$ Soc Trop Med Hyg. 2004;98(8):485-8.

16. Mason J, Greiner T, Shrimpton R, Sanders D, Yukich J. Vitamin A policies need rethinking. Int J Epidemiol. 2014;44(1):283-92.

17. da Silva JV, Timoteo AK, dos Santos CD, Fontes G, da Rocha EM. [Food consumption of children and adolescents living in an area of invasion in Maceio, Alagoas, Brazil]. Rev Bras Epidemiol. 2010;13(1):83-93.

18. Akhtar S, Ahmed A, Randhawa MA, Atukorala S, Arlappa N, Ismail T, et al. Prevalence of vitamin A deficiency in South Asia: causes, outcomes, and possible remedies. J Health Popul Nutr. 2013;31(4):413-23.

19. World Health Organization. Global prevalence of vitamin A deficiency in populations at risk 1995-2005. Geneva:World Health Organization; 2009 [cited 2015 Jany 22]. Available from: http://www.who.int/vmnis/vitamina/en/.

20. Clagett-Dame M, Knutson D. Vitamin A in reproduction and development. Nutrients. 2011;3(4):385-428

21. Muniz-Junqueira MI, Queiroz EF. Relationship between protein-energy malnutrition, vitamin A, and parasitoses in living in Brasilia. Rev Soc Bras Med Trop. 2002;35(2):133-41.

22. Payne LG, Koski KG, Ortega-Barria E, Scott ME. Benefit of vitamin A supplementation on ascaris reinfection is less evident in stunted children. J Nutr. 2007;137(6):1455-9.

23. Suchdev PS, Davis SM, Bartoces M, Ruth $\sqcup$, Worrell CM, Kanyi H, et al. Soil-transmitted helminth infection and nutritional status among urban slum children in Kenya. Am J Trop Med Hyg. 2014;90(2):299-305.

24. Moreira DS, Rocha GM. Toxocara canis: impact of preweaning nutritional deprivation on the pathogenesis of pneumonia in the mouse. Exp Parasitol. 2005;110(4):349-52.

25. McLaughlin S, Welch J, MacDonald E, Mantry S, Ramaesh K. Xerophthalmia--a potential epidemic on our doorstep? Eye (Lond). 2014;28(5):621-3.

26. Sharma A, Aggarwal S, Sharma V. Bitot's Spots: Look at the Gut. Int J Prev Med. 2014; 5(8):1058-9.

27. Figueiredo JF, Lorenzato MM, Silveira SA, Passos AD, Rodrigues M, Galvao LC, et al. [Survival and infectious processes in pacients with AIDS: analysis based on initial serum vitamin A levels]. Rev Soc Bras Med Trop. 2001;34(5):429-35.

28. Suan EP, Bedrossian EH Jr, Eagle RC Jr, Laibson PR. Corneal perforation in patients with vitamin A deficiency in the United States. Arch Ophthalmol. 1990;108(3):350-3.

29. Ansari EA, Sahni K, Etherington C, Morton A, Conway SP, Moya E, et al. Ocular signs and symptoms and vitamin A status in patients with cystic fibrosis treated with daily vitamin A supplements. Br J Ophthalmol. 1999;83(6):688-91.

30. Brooks HL Jr, Driebe WT Jr, Schemmer GG. Xerophthalmia and cystic fibrosis. Arch Ophthalmol. 1990;108(3):354-7.

31. Phillips JR, Angulo P, Petterson T, Lindor KD. Fat-soluble vitamin levels in patients with primary biliary cirrhosis. Am J Gastroenterol. 2001;96(9):2745-50.

32. Bors F, Fells P. Reversal of the complications of self-induced vitamin A deficiency. Br J Ophthalmol. 1971;55(3):210-4

33. Olver J. Keratomalacia on a 'healthy diet'. Br J Ophthalmol. 1986;70(5):357-60.

34. Ramsay A, Sabrosa NA, Pavesio CE. Bitot's spots and vitamin A deficiency in a child from the UK. Br J Ophthalmol. 2001;85(3):372.

35. Jaworowski S, Drabkin E, Rozenman Y. Xerophthalmia and undiagnosed eating disorder. Psychosomatics. 2002;43(6):506-7.

36. Templeton SB, Marlette MA, Panemangalore M. Competitive foods increase the intake of energy and decrease the intake of certain nutrients by adolescents consuming school lunch. J Am Diet Assoc. 2005;105(2):215-20.

37. Walsh BT, Devlin MJ. Eating disorders: progress and problems. Science. 1998;280 (5368):1387-90.

38. Mitchell JE, Crow S. Medical complications of anorexia nervosa and bulimia nervosa. Curr Opin Psychiatry. 2006;19(4):438-43.
39. Lee WB, Hamilton SM, Harris JP, Schwab IR. Ocular complications of hypovitaminosis a after bariatric surgery. Ophthalmology. 2005;112(6):1031-4

40. Donaldson KE, Fishler J. Corneal ulceration in a LASIK patient due to vitamin a deficiency after bariatric surgery. Cornea. 2012;31(12):1497-9.

41. Ramos-Levi AM, Perez-Ferre N, Sanchez-Pernaute A, Torres Garcia AJ, Rubio Herrera MA. Severe vitamin A deficiency after malabsortive bariatric surgery. Nutr Hosp. 2013; 28(4):1337-40.

42. Pereira S, Saboya C, Chaves G, Ramalho A. Class III obesity and its relationship with the nutritional status of vitamin A in pre- and postoperative gastric bypass. Obes Surg. 2009;19(6):738-44.

43. Szodoray P, Horvath IF, Papp G, Barath S, Gyimesi E, Csathy L, et al. The immunoregulatory role of vitamins $A, D$ and $E$ in patients with primary Sjogren's syndrome. Rheumatology (Oxford). 2010;49(2):211-17.

44. Backstrom I, Funegard U, Andersson I, Franzen L, Johansson I. Dietary intake in head and neck irradiated patients with permanent dry mouth symptoms. Eur J Cancer B Oral Oncol. 1995;31B(4):253-7.

45. Aktas S, Sagdik HM, Aktas H, Gulcan E, Tetikoglu M, Cosgun S, et al. Tear function in patients with chronic renal failure undergoing hemodialysis. Renal Fail. 2015;37(2):245-8.

46. Jung JW, Yoon MH, Lee SW, Chin HS. Effect of hemodialysis (HD) on intraocular pressure, ocular surface, and macular change in patients with chronic renal failure. Effect of hemodialysis on the ophthalmologic findings. Graefes Arch Clin Exp Ophthalmol. 2013;251(1):153-62.

47. Riccioni G, D Orazio N, Scotti L, Petruzzelli R, Latino A, Bucciarelli V, et al. Circulating plasma antioxidants, inflammatory markers and asymptomatic carotid atherosclerosis in end-stage renal disease patients: a case control study. Int J Immunopathol Pharmacol. 2010;23(1):327-34.

48. Espe KM, Raila J, Henze A, Krane V, Schweigert FJ, Hocher B, et al. Impact of vitamin A on clinical outcomes in haemodialysis patients. Nephrol Dial Transplant. 2011;26(12): 4054-61.

49. Nishida T, Sawada A, Mochizuki K, Niwa Y, Hayakawa K. Case of acquired night blindness in a hemodialysis patient. Can J Ophthalmol. 2013;48(6):e148-51.

50. Kim EC, Choi JS, Joo CK. A comparison of vitamin a and cyclosporine a 0.05\% eye drops for treatment of dry eye syndrome. Am J Ophthalmol. 2009;147(2):206-13.e3.

51. Kobayashi TK, Tsubota K, Takamura E, Sawa M, Ohashi Y, Usui M. Effect of retinol palmitate as a treatment for dry eye: a cytological evaluation. Ophthalmologica. 1997; 211(6):358-61.

52. Samarawickrama C, Chew S, Watson S. Retinoic acid and the ocular surface. Surv Ophthalmol. 2015;60(3):183-95.

53. Mamede AC, Tavares SD, Abrantes AM, Trindade J, Maia JM, Botelho MF. The role of vitamins in cancer: a review. Nutr Cancer. 2011;63(4):479-94.

54. Allen LH, Haskell M. Estimating the potential for vitamin A toxicity in women and young children. J Nutr. 2002;132(9 Suppl):2907S-19S.

55. Oliveira MR. The neurotoxic effects of vitamin A and retinoids. An Acad Bras Cienc. 2015:97(2):1361-73.

56. Tan X, Takahashi H, Nishida J, Aoki A, Inoue T, Yanagi Y. Excessive retinol intake exacerbates choroidal neovascularization through upregulated vascular endothelial growth factor in retinal pigment epithelium in mice. Exp Eye Res. 2015;131:77-83.

57. Fraunfelder FT, LaBraico JM, Meyer SM. Adverse ocular reactions possibly associated with isotretinoin. Am J Ophthalmol. 1985;100(4):534-7.

58. McGeeney BE, Friedman DI. Pseudotumor cerebri pathophysiology. Headache. 2014; 54(3):445-58.

59. Tanumihardjo SA. Vitamin A: biomarkers of nutrition for development. The Am J Clin Nutr. 2011:94(2):658S-65S

60. Sommer A, Davidson FR; Annecy Accords. Assessment and control of vitamin A deficiency: the Annecy Accords. J Nutr. 2002;132(9 Suppl):2845S-50S.

61. Wittpenn JR, Tseng SC, Sommer A. Detection of early xerophthalmia by impression cytology. Arch Ophthalmol. 1986;104(2):237-9. 